九州大学学術情報リポジトリ

Kyushu University Institutional Repository

Identifications of Some Species of the Genus

Rhopalomyia (Diptera : Cecidomyiidae) Inducing Galls on Artemisia (Asteraceae) in South Korea

Ganaha, Tomoko

Yukawa, Junichi

Uechi, Nami

Nohara, Machiko

他

https://doi.org/10.5109/2681

出版情報: ESAKIA. 44，pp.45-55，2004-03-31. Entomological Laboratory，Faculty of Agriculture， Kyushu University

バージョン：

権利関係 : 


\title{
Identifications of Some Species of the Genus Rhopalomyia (Diptera: Cecidomyiidae) Inducing Galls on Artemisia (Asteraceae) in South Korea*
}

\author{
Tomoko GANAHA, Junichi YUKAWA
}

Entomological Laboratory, Faculty of Agriculture, Kyushu University, Fukuoka, 812-8581 Japan

\section{Nami UECHI, Machiko NOHARA}

Entomological Laboratory, Graduate School of Bioresource and Bioenvironmental Sciences, Kyushu University, Fukuoka, 812-8581 Japan

and

\section{Jong-Cheol PAIK}

Department of Applied Biology, Sunchon National University,

Jeonnam, 540-742 Korea

\begin{abstract}
In 2003, four species of the genus Rhopalomyia (Diptera: Cecidomyiidae) were collected from Artemisia species (Asteraceae) in South Korea. To identify these species, morphological features, gall appearance, host plant species, and DNA sequence data of each species were compared with those of respective Rhopalomyia species that induce similar galls on Artemisia species in Japan. Three of the four South Korean Rhopalomyia species were identical with Japanese Rhopalomyia species, respectively; they are $R$. struma, $R$. yomogicola, and Rhopalomyia sp. that induces globular axillary bud galls. In the case of Rhopalomyia sp., DNA sequence data indicated that speciation could be initiated by geographical isolation prior to host shifting. Remaining one species that was collected from terminal bud galls on Artemisia capillaris in South Korea was different from the Japanese species that induces a similar gall on $A$. princeps and A. montana. This South Korean gall midge will be described as a new species elsewhere in the future.
\end{abstract}

Key words: Rhopalomyia, Cecidomyiidae, Artemisia, gall, Korea, speciation.

* Contribution from the Entomological Laboratory, Faculty of Agriculture, Kyushu University, Fukuoka (Ser. 5, No. 109). 


\section{Introduction}

About 250 species of the genus Artemisia Linnaeus (Asteraceae) have been recorded in the world. In Japan, there are 31 Artemisia species, consisting of 24 in the section Artemisia and seven in the section Dracunculus (Satake et al., 1981; Hotta et al., 1989). Twelve Japanese gall midge species of the genus Rhopalomyia Rübsaamen, 1892 (Diptera: Cecidomyiidae) are known to utilize Artemisia feddei Léveillé et Vaniot, Artemisia montana (Nakai) Pampan, and Artemisia princeps Pampan in the section Artemisia, and Artemisia capillaris Thunberg and Artemisia japonica Thunberg in the section Dracunculus as their host plants (Yukawa \& Masuda, 1996).

From the Korean Peninsula and surrounding islands (Korea, hereafter), at least 30 gall-inducing species of Cecidomyiidae (Diptera) have been recorded (Saitô, 1932; ESK \& KSAE, 1994; Yukawa \& Masuda, 1996; Kodoi et al., 2003). Four species of them have been identified as members of Rhopalomyia based on similarities of the appearance and structure of their galls to those induced by Japanese gall midges on Artemisia species. They are Rhopalomyia struma Monzen, 1937, Rhopalomyia giraldii Kieffer et Trotter, 1900, Rhopalomyia yomogicola (Matsumura, 1931), and Rhopalomyia artemisiae (Bouché, 1834).

In many cases, the appearance and structure of midge galls are specific to gall-midge species, and each gall is induced on particular plant taxa. Therefore, the galls are regarded as an extended phenotype of respective gall-midge species, except for some polyphagous species (e.g., Yukawa et al., 2003; Uechi et al., 2003; Uechi et al., 2004). Thus, the identification of these Korean Rhopalomyia species based on host plant and gall information seems to be reliable. However, it would be better to confirm the identification at the DNA level because there are some instances in which gall midges are different even when they induce the same sort of gall on the same host organ and species (Uechi et al., unpublished data).

In addition, comparison between the variation of haplotypes from different localities and that of haplotypes from different host plants will provide us with useful information about which of the factors, geographical isolation or host plant shift, primarily affect speciation of gall midges.

This paper intends to identify four species of Rhopalomyia that were collected from Sunchon, Jeonnam and its vicinity, South Korea. The identification was based not only on the morphological features of gall midges and the appearance of their galls but also on DNA sequence data, with which influence of the two factors, geographical isolation and host plant shift, on speciation were compared. 


\section{Materials and Methods}

\section{Collection and preservation of specimens}

Three sorts of gall on A. princeps, and one on A. capillaris were collected on May 28, 2003 from Sunchon, Jeonnam and its vicinity, the most southern parts of the Korean Peninsula. Among them, two sorts on A. princeps have been recorded from Korea; one is similar to a stem gall (Photograph Number: D-102 in Yukawa \& Masuda, 1996) induced by $R$. struma in Japan and another is to a subconical leaf gall (D-112) induced by $R$. yomogicola in Japan. Remaining one on A. princeps is similar to an axillary bud gall (D-110) induced by Rhopalomyia species in Japan, but it was not recorded previously from Korea. The last one on A. capillaris was not found previously both in Japan and Korea, although its appearance is similar to a terminal bud gall induced by Rhopalomyia abdominalis Shinji, 1938 on A. montana or to that (D-108) by Rhopalomyia iwatensis Shinji, 1938 on A. japonica and A. princeps in Japan.

Some of these galls were dissected under a binocular microscope and unparasitized mature midge larvae and pupae were picked out of the galls and kept in 70-75\% ethanol for morphological studies or in $99.5 \%$ acetone for DNA analysis. Remaining galls were maintained in plastic containers $(10 \mathrm{~cm}$ in diameter, $6 \mathrm{~cm}$ in depth) to rear adult midges. Emerged adults were also put into $70-75 \%$ ethanol or $99.5 \%$ acetone.

\section{Morphological study and identification of $\mathbb{R}$ hopalomyia species}

At the time of dissecting galls, appearance and inner structure of the galls collected from South Korea were examined. The South Korean gall midges obtained from these galls were compared, respectively, with Japanese Rhopalomyia species inducing galls that are similar to those collected from South Korea.

The full-grown larvae, pupae, and adults that had been stored in 70-75\% ethanol were mounted on slides in Canada balsam for microscopic study, based on the techniques outlined in Gagné (1989). These specimens were examined with a brightfield and phase-contrast microscopy, a Nikon ECLIPSE E400 microscope. Special attention was paid to dorsal and ventral papillae on larval prothorax, larval terminal segment, and pupal antennal sheath and frontal area, since they frequently exhibit species-specific features.

The slide-mounted specimens examined in this study are kept in the collection of Entomological Laboratory, Faculty of Agriculture, Kyushu University, Fukuoka, Japan.

\section{DNA extraction, amplification, and sequencing}

At least three individuals of each species were used for DNA analysis. For every individual, total DNA was extracted from the whole body with the Dneasy tissue kit 
(Qiagen, Japan), following the manufacturer's instructions. A region of the cytochrome oxidase subunit I (COI) gene of mtDNA was amplified by PCR following the methods described by Yukawa et al. (2003). DNA of each specimen was amplified using the following primers: forward; 5'-GGATCACCTGATATAGCATTCCC-3' (COIS) and reverse; 5'-CCCGGTAAAATTAAAATATAAACTTC-3' (COIA). These primers have been effectively used for many gall midges to determine intra- and inter-specific relations (e.g., Shirota et al., 1999; Yukawa et al., 2003; Uechi et al., 2003; Uechi et al., 2004). The amplified COI gene fragment of mtDNA was 439 bp long. This region corresponded to the bases 1752-2190 of the genome of Drosophila yakuba Burla (Diptera: Drosophilidae) (Clary \& Wolstenholme, 1985).

The amplified products were purified with the QiAquick PCR purification kits (Qiagen, Japan) following the manufacturer's instructions. The purified products were sequenced by the dideoxy-nucleotide cycle sequencing procedure with the DyeTerminator cycle sequencing kit (Perkin-Elmer, Warrington, UK) and TGRADIENT thermal cycler (Biometrica). Sequencing electrophoresis was done on an $11 \%$ Long Ranger $^{\mathrm{TM}}$ gel with a LIC-4200S-2 automated DNA sequencer (Aloka Co. Ltd., USA). Both strands of the PCR products were sequenced.

\section{Molecular phylogenetic analysis}

Phylogenetic analysis was conducted by the neighbor-joining (NJ) method (Saitou \& Nei, 1987) using the software package PHYLIP ver. 3.573c (Felsenstein, 1993). The resulting trees were evaluated by the bootstrap test (Efron, 1982; Felsenstein, 1985) based on 1,000 replications.

As outgroup taxa in the above analysis, the following two gall-midge species (Diptera: Cecidomyiidae) were used (Table 1): Contarinia okadai (Miyoshi) infesting the blossoms of Citrus spp. (Rutaceae) and Asphondylia yushimai Yukawa et Uechi, an important pest of soybean in Japan.

Nucleotide sequence data obtained in this study are registered with DDBJ (DNA Data Bank of Japan), EMBL (European Molecular Biology Laboratory), and GenBank nucleotide sequence databases (Table 1).

\section{Results}

\section{Rhopalomyia struma-like gall midge inducing stem galls in South Korea}

Eight haplotypes were found in the sequential variations of $R$. struma in Japan and one haplotype in the South Korean $R$. struma-like gall midge (Fig. 1). Among the eight haplotypes of $R$. struma, there were one $(0.23 \%)$ to $12(2.73 \%)$ bp differences, and at most three differences in the 146 deduced amino acid residues. The South Korean 
haplotype was one $(0.23 \%)$ to eight $(1.82 \%)$ bp different from the haplotypes of $R$. struma and there were one to three differences in the amino acid residues. However, the South Korean haplotype was included in the clade of $R$. struma. The monophyly of the clade including the South Korean haplotype and Japanese $R$. struma was supported by a

Table 1. Specimens used for DNA analysis: two species of Rhopalomyia galling on Artemisia in South Korea and Japan and two outgroup species of gall midges, Contarinia okadai and Asphondylia yushimai.

\begin{tabular}{|c|c|c|c|c|}
\hline Gall midge & Host plant & Collection site & Isolation name & $\begin{array}{l}\text { Accession } \\
\text { no** }\end{array}$ \\
\hline \multirow[t]{13}{*}{ Rhopalomyia sp. } & \multirow[t]{13}{*}{ A.princeps } & Rifu, Miyagi, Japan & mmtbprimyg01 & $\mathrm{AB} 162385$ \\
\hline & & \multirow[t]{2}{*}{ Hakozaki, Fukuoka, Japan } & mmtbprifuk02 & $\mathrm{AB} 162386$ \\
\hline & & & mmtbprifuk03 & AB162387 \\
\hline & & Yufuin, Oita, Japan & mmtbprioit04 & $\mathrm{AB} 162388$ \\
\hline & & \multirow[t]{2}{*}{ Kokonoe, Oita, Japan } & mmtbprioit05 & AB 162389 \\
\hline & & & mmtbprioit06 & $\mathrm{AB} 162390$ \\
\hline & & Ume, Oita, Japan & mmtbprioit07 & $\mathrm{AB} 162391$ \\
\hline & & \multirow[t]{3}{*}{ Kitagawa, Miyazaki, Japan } & mmtbprimyz08 & AB 162392 \\
\hline & & & mmtbprimyz09 & AB 162393 \\
\hline & & & mmtbprimyz10 & AB162394 \\
\hline & & \multirow[t]{3}{*}{ Sunchon, Jeonnam, South Korea } & mmtbprikor11 & AB162395 \\
\hline & & & mmtbprikor 12 & AB162396 \\
\hline & & & mmtbprikor 13 & AB 162397 \\
\hline \multirow[t]{23}{*}{ R. struma } & \multirow[t]{2}{*}{ A. montana } & \multirow[t]{2}{*}{ Bibai, Hokkaido, Japan } & kukimonhok14 & AB162398 \\
\hline & & & kukimonhok15 & AB162399 \\
\hline & \multirow[t]{21}{*}{ A.princeps } & \multirow[t]{2}{*}{ Higashinaruse, Akita, Japan } & kukipriaki16 & AB 162400 \\
\hline & & & kukipriaki17 & $\mathrm{AB} 162401$ \\
\hline & & \multirow[t]{2}{*}{ Kureha, Toyama, Japan } & kukipritym 18 & AB 162402 \\
\hline & & & kukipritym 19 & $\mathrm{AB} 162403$ \\
\hline & & Bunkyo, Fukui, Japan & kukiprifki20 & $\mathrm{AB} 162404$ \\
\hline & & \multirow[t]{3}{*}{ Misumi, Shimane, Japan } & kukiprismn21 & AB162405 \\
\hline & & & kukiprismn22 & $\mathrm{AB} 162406$ \\
\hline & & & kukiprismn23 & AB162407 \\
\hline & & \multirow[t]{3}{*}{ Kitakyushu, Fukuoka, Japan } & kukiprifuk24 & AB162408 \\
\hline & & & kukiprifuk25 & AB162409 \\
\hline & & & kukiprifuk26 & AB 162410 \\
\hline & & \multirow[t]{4}{*}{ Yufuin, Oita, Japan } & kukiprioit27 & AB 162411 \\
\hline & & & kukiprioit28 & AB162412 \\
\hline & & & kukiprioit29 & $\mathrm{AB} 162413$ \\
\hline & & & kukiprioit30 & $\mathrm{AB} 162414$ \\
\hline & & \multirow[t]{3}{*}{ Kitagawa, Miyazaki, Japan } & kukiprimyz31 & $\mathrm{AB} 162415$ \\
\hline & & & kukiprimyz32 & AB162416 \\
\hline & & & kukiprimyz33 & AB 162417 \\
\hline & & \multirow[t]{3}{*}{ Sunchon, Jeonnam, South Korea } & kukiprikor34 & $\mathrm{AB} 162418$ \\
\hline & & & kukiprikor35 & AB162419 \\
\hline & & & kukiprikor36 & $\mathrm{AB} 162420$ \\
\hline \multicolumn{5}{|l|}{ Out group } \\
\hline Contarinia okadai & Citrus iyo & Tachibana, Yamaguchi, Japan & ConokaYG-T267 & $\mathrm{AB} 105485$ \\
\hline Asphondylia yushimai & Glycine $\max$ & Chikushino, Fukuoka, Japan & SoyFuk15 & AB085787 \\
\hline
\end{tabular}

\footnotetext{
* Nucleotide sequence data used in this study are available from DDBJ, EMBL, and GenBank.
} 
Contarinia okadai Asphondylia yushimai

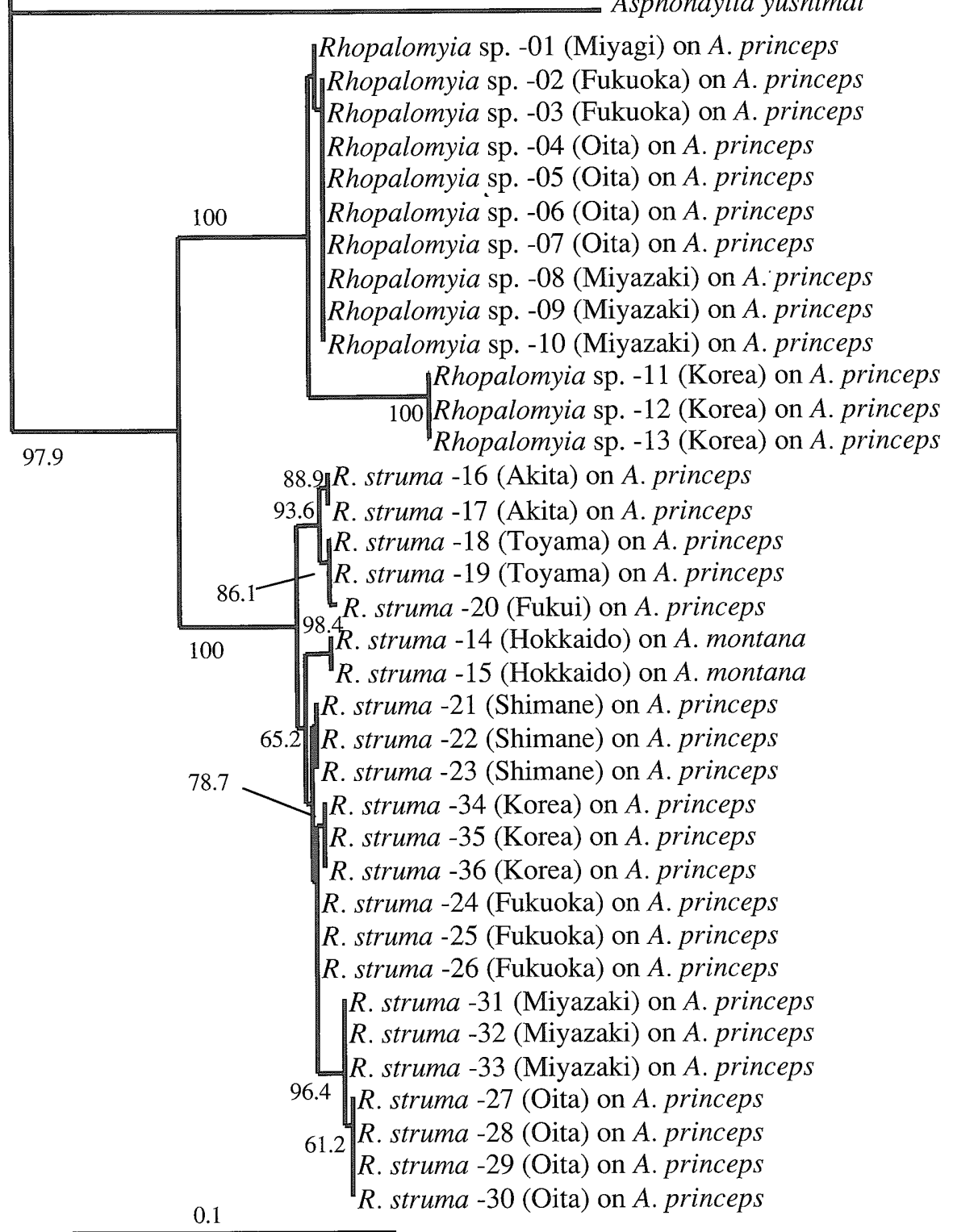

Fig. 1. NJ-tree based on 439 bp of the mtDNA COI gene for two Artemisia gall midges, Rhopalomyia struma and Rhopalomyia sp., from South Korea and Japan. Bootstrap values are indicated for nodes gaining more than $60 \%$ support (1,000 replications). Contarinia okadai and Asphondylia yushimai were used as outgroup species. Sample numbers correspond to the respective isolation names registered in DNA database (see Table 1). 

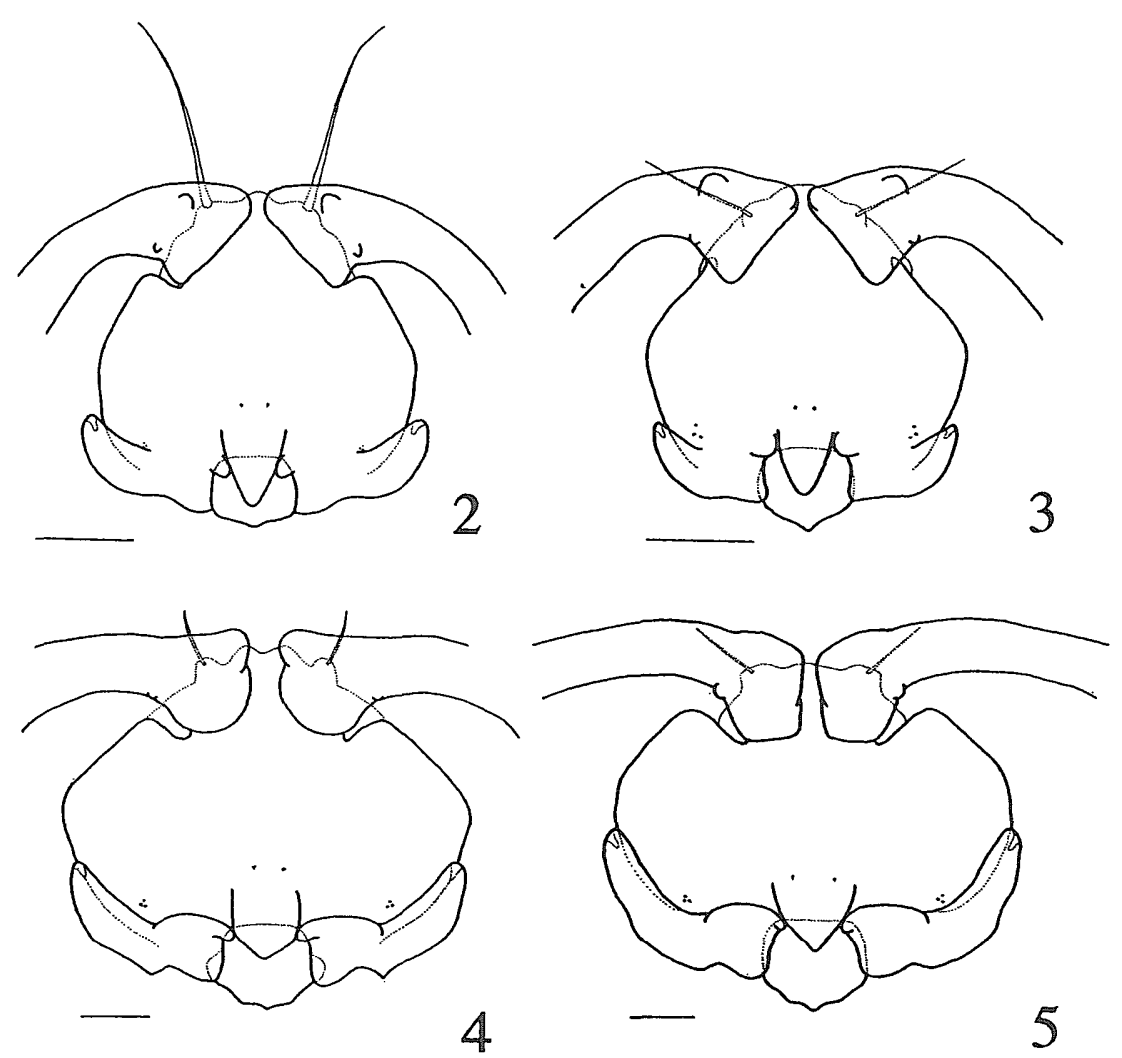

Figs. 2-5. Ventral view of pupal head (Scale bar $=0.1 \mathrm{~mm}$ ). 2: Rhopalomyia struma from South Korea, 3: Rhopalomyia struma from Japan, 4: Rhopalomyia sp. inducing axillary bud galls in South Korea, and 5: Rhopalomyia sp. inducing axillary bud galls in Japan.

$100 \%$ bootstrap value (Fig. 1). Morphological features, particularly those of pupal frontal area and the basal portion of antenna in pupa, also supported the identity between the South Korean (Fig. 2) and Japanese species (Fig. 3).

\section{Rhopalomyia yomogicola-like gall midge inducing subconical leaf galls in South Korea}

At least 23 haplotypes were found in the sequential variations of $R$. yomogicola in Japan and three in the South Korean $R$. yomogicola-like gall midge. These South Korean haplotypes were included here and there in small, scattered clades consisting of a few Japanese haplotypes. NJ-tree was not indicated in this paper for R. yomogicola because further DNA analysis in different regions is required to confirm if these 
scattered clades are unified into a main clade of $R$. yomogicola.

\section{Rhopalomyia sp. inducing globular axillary bud galls in South Korea}

As to the Japanese Rhopalomyia species that induces globular galls on the axillary buds, there were two haplotypes in the individuals collected from Miyagi Prefecture and various prefectures in Kyushu (Fig. 1). Only one haplotype was found in the individuals of the South Korean Rhopalomyia species that induces globular axillary bud galls. Between the two haplotypes of the Japanese Rhopalomyia species, there were one $(0.23 \%)$ bp difference, and only one difference in the 146 deduced amino acid residues. The South Korean haplotype was $14(3.19 \%)$ to 15 (3.42\%) bp different from the Japanese haplotypes and there were seven to eight differences in the amino acid residues. However, the South Korean haplotype was included in the clade of the Japanese Rhopalomyia species. The monophyly of the clade including the South Korean haplotype and the Japanese Rhopalomyia species was supported by a $100 \%$ bootstrap value (Fig. 1).

There were slight morphological differences in pupa between the South Korean and the Japanese species: base of antenna slightly developed anteriorly into a rounded lobe in the South Korean species (Fig. 4), while undeveloped and gently rounded in the Japanese species (Fig. 5).

\section{Rhopalomyia sp. inducing terminal bud galls in South Korea}

The Rhopalomyia species that induces terminal bud galls on A. capillaris in South Korea was morphologically different in the basal portion of pupal antennal horn from $R$. abdominalis on A. montana and $R$. iwatensis on A. japonica and A. princeps in Japan. Sequencing data also supported the difference. These data are not indicated in this paper, because the South Korean species will be described as a new species in a separate paper.

\section{Discussion}

Morphological features and DNA analysis indicated that three of the four South Korean Rhopalomyia species were identical with the Japanese Rhopalomyia species on Artemisia, respectively. They were $R$. struma, $R$. yomogicola, and the Rhopalomyia species that induces globular axillary bud galls. These results revealed that the species identification based on host plant and gall information was reliable at least for the interrelation between Artemisia and Rhopalomyia in South Korea and Japan.

Differences in the sequential variations of $R$. struma were very small between South Korean and Japanese populations and between different host plants, A. princeps and $A$. montana (Fig. 1). This means that diversification does not proceed in $R$. struma between 
the two areas and between the different host plants.

In contrast, there were relatively big differences between South Korean and Japanese populations in the sequential variations of the Rhopalomyia species that induces globular axillary bud galls on A. princeps (Fig. 1). In addition, there were slight morphological differences in the base of pupal antenna between the South Korean and the Japanese populations (Figs. 4, 5). Such differences do not mean that they are different species at the moment, but may suggest that they began to speciate.

In Japan, the Rhopalomyia species is known to induce the same sort of gall also on $A$. montana (Yukawa \& Masuda, 1996), and preliminary DNA analysis showed relatively small sequential differences between populations on $A$. princeps, A. montana, and $A$. feddei (Ganaha et al., unpublished data). In the case of the Rhopalomyia species, diversification could be initiated by geographical isolation prior to host plant shift.

As a result, the number of Rhopalomyia species in Korea stood at six, although the two previously recorded species, $R$. giraldii and $R$. artemisiae, could not be examined in this study.

\section{Acknowledgements}

We are grateful to Dr. Y.-C. Jung (Department of Biology, Sunchon National University) for identifications of Artemisia species in South Korea, and to Mr. S. Sato (Entomological Laboratory, Kyushu University) for his help in preparing slide-mounted specimens. Three of us, T. Ganaha, N. Uechi, and M. Nohara, thank Dr. O. Tadauchi, Dr. S. Kamitani, and Mr. D. Yamaguchi (Entomological Laboratory, Kyushu University) for their encouragements.

\section{References}

Bouché, P. F., 1834. Naturgeschichte der Insekten, besonders in Hinsicht ihrer ersten Zustände als Larven und Puppen. 1. vi + 216 pp. 10 pls., Nicolaischen Buchhandlung, Berlin.

Clary, D. O. \& D. R. Wolstenholme, 1985. The mitochondrial DNA molecule of Drosophila yakuba: nucleotide sequence, gene organization, and genetic code. $J$. Mol. Evol., 22: 252-271.

Efron, B., 1982. The Jackknife, the Bootstrap, and Other Resampling Plans. 92 pp. Society for Industrial and Applied Mathematics, Philadelphia.

ESK \& KSAE (The Entomological Society of Korea and The Korean Society of Applied Entomology), 1994. Check List of Insects from Korea. 744 pp., Kon-Kuk University Press, Seoul. 
Felsenstein, J., 1985. Confidence limits on phylogenies: an approach using the bootstrap. Evolution, 39: 783-791.

Felsenstein, J., 1993. PHYLIP (Phylogeny Inference Package) Version 3.5c. University of Washington, Seattle.

Gagné, R. J., 1989. The Plant-feeding Gall Midges of North America. 355 pp., Cornell University Press, Ithaca, New York.

Gagné, R. J., 2004. A catalog of the Cecidomyiidae (Diptera) of the world. Mem. Entomol. Soc. Wash., 25: 1-408.

Hotta, M., K. Ogata, A. Nitta, K. Hoshikawa, M. Yanagi \& K. Yamazaki, 1989. Useful Plants of the World. 1499 pp., Heibonsha, Tokyo. (In Japanese.)

Kieffer, J. J. \& A. Trotter, 1900. Description d'une Cecidomyie nouvelle de Chine. Bull. Soc. ent. Fr., 1900: 233.

Kodoi, F., H.-S. Lee, N. Uechi \& J. Yukawa, 2003. Occurrence of Obolodiplosis robiniae (Diptera: Cecidomyiidae) in Japan and South Korea. Esakia, (43): 35-42.

Matsumura, S., 1931. 6000 Illustrated Insects of Japanese-Empire. p. 403, Koutou Shoin, Tokyo. (In Japanese.)

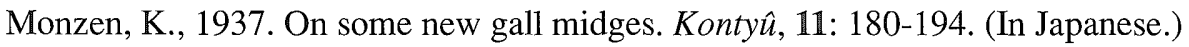

Saitô, K., 1932. [Studies of insect galls in Korea]. Bull. Sci. Res. Alumni Assoc. Morioka Coll. Agr. Forest., (7): 93-107. (In Japanese.)

Saitou, N. \& M. Nei, 1987. The neighbor-joining method: a new method for reconstructing phylogenetic trees. Mol. Biol. Evol., 4: 406-425.

Satake, Y., H. Hara, S. Watari \& T. Tominari, 1981. Wild Flowers of Japan. Herbaceus Plants III. 259 pp., Heibonsha, Tokyo. (In Japanese.)

Shinji, O., 1938. Four new and one known species of gall midges from Japan. Ins. World, 42: 335-340. (In Japanese.)

Shirota, Y., K. Iituka, J. Asano, J. Abe \& J. Yukawa, 1999. Intraspecific variations of mitochondrial cytochrome oxidase I sequence in an aphidophagous species, Aphidoletes aphidimyza (Diptera: Cecidomyiidae). Entomol. Sci., 2: 209-215.

Uechi, N., M. Tokuda, J. Yukawa, F. Kawamura, K. K. Teramoto \& K. M. Harris, 2003. Confirmation by DNA analysis that Contarinia maculipennis (Diptera: Cecidomyiidae) is a polyphagous pest of orchids and other unrelated cultivated plants. Bull. ent. Res., 93: 545-551.

Uechi, N., J. Yukawa \& D. Yamaguchi, 2004. Host alternation by gall midges of the genus Asphondylia (Diptera: Cecidomyiidae), pp. 53-66. In Evenhuis, N. L. \& K.Y. Kaneshiro (eds.), Contributions to the Systematics and Evolution of Diptera. D. Elmo Hardy Mem.Vol. Bishop Mus. Bull. Entomol., 12.

Yukawa, J. \& H. Masuda, 1996. Insect and Mite Galls of Japan in Colors. 826 pp., Zenkoku Nôson Kyôiku Kyôkai, Tokyo. (In Japanese with English explanations for 
color plates.)

Yukawa, J., N. Uechi, M. Horikiri \& M. Tuda, 2003. Description of the soybean pod gall midge, Asphondylia yushimai sp. n. (Diptera: Cecidomyiidae), a major pest of soybean and findings of host alternation. Bull. ent. Res., 93: 73-86. 


\section{.}

